\title{
Oral Abstracts
}

\section{Nutrition Education and Food Systems for Community}

\section{Extension Master Food Volunteer Program: Integrating Food Systems Into Community Engagement About Nutrition and Cooking}

Dara Bloom,PhD, jdbloom@ncsu.edu, NC State University, 512 Brickhaven Drive, Raleigh, NC 27695; Joanna Lelekacs, PLA, LEED, AP, ND

Objective: The food systems section of the North Carolina Extension Master Food Volunteer (EMFV) curriculum is designed to prepare Family and Consumer Science (FCS) Extension agents and volunteers to integrate food systems education into nutrition and cooking classes, support local food system projects, and respond to consumers' food systems-related questions.

Target Audience: FCS Extension agents and EMFV volunteers. Theory, Prior Research, Rationale: Research shows that when people participate more directly in the food system, either through awareness of the origins of their food or by growing their own, they increase their consumption of fruits and vegetables.

Description: The EMFV curriculum is a 30-hour training on FCS topics, including nutrition, food safety, and cooking. The food systems section includes introductions to terminology, research about local food impacts, and place-based project examples. The EMFV program was piloted with seven FCS agents and 39 volunteers in 20162017, providing 937 service hours to 2,382 contacts through classes, farmers' markets, health fairs, food pantries, and other community locations and events.

Evaluation: Training evaluation assessed participants' knowledge and confidence related to food systems topics. Simple statistics were used to analyze retrospective pre and post knowledge test data. Interviews and focus groups were conducted with the five FCS agents and 20 volunteers who had completed one year of the pilot program in 2017.

Conclusions and Implications: Quantitative data analysis indicated that the majority of participants increased their knowledge in the food systems section of the training, and all participating agents felt prepared to train volunteers. FCS agents reported increased confidence to teach about food systems, although additional training was requested. Agents and volunteers were aware of the need to prioritize nutrition messages to consumers in the context of food system education, including concern that lowincome consumers might feel they couldn't be healthy if they couldn't afford local or organic products.

Funding: NC Cooperative Extension.

\section{The Role of Collaboration and Community Engagement in Improving Food Systems}

Diane Smith, MA, RD, diane.smith@wsu.edu, WSU

Extension, Skagit and Whatcom Counties, 11768 Westar

Lane, Suite A, Burlington, WA 98233; Matia Jones, BA,

Western Washington University; Mardi Solomon, $M A$,
Whatcom Farm to School; Diana Meeks, BA, Sustainable Connections

Objective: Community food networks vary widely, and as a result, efforts to improve local food systems will vary. In the midst of all this variety is one constant: people working together. In Whatcom County, the Whatcom Food Network (WFN) was established through an intentional process of building a coalition of food and farming community members-nutrition experts, food advocates, educators, farmers, and agency representatives-with a shared vision and commitment to understand and improve the local food system. WFN's mission is to build common understanding and facilitate collaborative efforts toward an equitable, sustainable, and healthy food system for all. Initiating a community food assessment was an effective method in bringing together stakeholders to describe the local food system and better understand the interplay between the different sectors within the food system. This case study describes best practices followed in building a collaboration to move the dial on a community food system to impact policy and improve food access for all community members. The bumps in the road became lessons learned, informing next steps in the process.

Target Audience: Food advocates, community food system workers, educators.

Theory, Prior Research, Rationale: Collaboration framework, Community Capital.

Description: This case study describes the organizational framework and process followed by the WFN in completing an initial community food assessment and the establishment of a coalition representing all sectors of the food system. A review of the literature related to collaborations, a brief overview of Whatcom County, and a discussion of the factors adopted by WFN that influenced the success of collaborative efforts will be presented. Evaluation: The success of the WFN is reflected in member engagement, participation in bi-annual forums for learning and information exchange, and adoption of food policies documented in the Whatcom County 5-year Plan.

Conclusions and Implications: The community food assessment can be an effective tool in marshaling energy and interest in local food systems; however, effective collaboration is critical to implementing and sustaining the desired changes.

Funding: Sustainable Whatcom Foundation.

\section{Powerful Food System Partnership_-Food Pantries + Waste Reduction Efforts}

Adrienne Markworth, MA, adrienne@leahspantrysf.org, Leah's Pantry, 5794 Caminito Empresa, La Jolla, CA 92037; Bethany Hendrickson, MPH

Objective: Food pantry sites receive more nourishing foods. Food waste reduction efforts include policies which prioritize nourishing foods and provide upstream strategies to divert non-nourishing foods from food pantries. 